\title{
Vállalkozási hajlandóság a Debreceni Egyetem hallgatói körében
}

\section{Entrepreneur willingness in case of students of University of Debrecen}

\author{
G. KuN \\ Debreceni Egyetem, Gazdaságtudományi Kar, Gazdálkodástudományi Intézet \\ (University of Debrecen, Faculty of Economics and Business Institute of Management Sciences) \\ H-4032 Debrecen, Böszörményi u. 138. \\ email:kun.gergo89@gmail.com
}

Absztrakt. A tanulmány célja a vállalkozási hajlandóság vizsgálata volt a Debreceni Egyetem hallgatói között, amelyben mintegy 500 hallgató mondhatta el véleményét a témakörröl kérdőív formájában. A kérdőivek eredményeinek kiértékelése lehetôséget biztosit arra, hogy a hallgató kifejthesse mi a véleménye a jelenlegi gazdasági helyzetrôl, érdemesnek tartják-e saját vállalkozást indtani illetve, milyen lehetőségeket és veszélyeket látnak ha vállalkozni kezdenek. Érdemes megvizsgálni, hogy az egyetem egyes karjain tanulú hallgatók milyen arányt képviselnek azok közül akik vállalkozóvá szeretének vállni, milyen családi háttérrel rendelkeznek és mindekez milyen hatással vannak a döntéshozatal során.

Abstract. This article is about the entrepeneur willingness in case of the students of University of Debrecen. There was 500 participants in the paper and online based survey who could tell their opinion about entrepreneurship in Hungary, what difficulties are they seeing and which part of the economy is where they see opportunity to start their own business. The aim of this article is to get to know how many of them and with what rate would like to start their own business, while it is examined they are from which faculty of the University, what is their family background and these facts how effects on the individual if his or her family owns some kind of business.

\section{Bevezetés}

Magyarországon napjainkban is a gazdasági ágazatok közül az egyik legmeghatározóbb szerepet a vállalkozói szektor tölti be, ezen belül pedig a kis- és középvállalkozások találhatóak meg a legnagyobb számban, konkrétan a vállalkozások 99 százalékát a kis- és középvállalkozások teszik ki, ezért rendkívül fontos, hogy a jövőben jól képzett és motivált vállalkozói réteg kerüljön ki a felsőoktatási intézményekből. A KSH adatai alapján a Magyarországon működő kkv-k aránya a 2016. évi adatok alapján az elmúlt évek adataihoz képest alig változott: 99,1\% volt az arányuk az összes vállalkozásból. A kkv-körön belül a mikrovállalkozások aránya 94,4, a kisvállalkozásoké 4,8, a középvállalkozásoké 0,8\% [1]. Ezért találtam fontosnak megvizsgálni azt, hogy a Debreceni Egyetem hallgatói körében a 
vállalkozói kedv és hajlandóság miként alakul. Ugyanis a karrierépítés előtt álló fiatal felnőttek számára nem feltétlenül vonzó a vállalkozói létforma, ez egyén függő, hogy ki milyen előnyét vagy hátrányát látja. Hiszen számos tényező, például az önállóság, lehet, hogy valaki számára előnyt jelent, mert a maga ura, úgy vezeti a vállalkozását, ahogy az elképzeléseiben szerepel, ugyanakkor más személy számára ez hátrány, mert olyan a személyisége, hogy jobban szereti, ha alkalmazotti viszonyban van, és valaki más adja ki számára az utasításokat. Jelen kutatás tárgya tehát, hogy választ kapjunk arra a kérdésre, hogy mennyire népszerű ma Magyarországon vállalkozónak lenni, milyen a vállalkozási kedv, erről pedig a Debreceni Egyetem mintegy 500 hallgatója által kitöltött kérdőív nyújt adatot.

Az elmúlt években számos projekt született a magyar állam, vagy az Európai Unió által finanszírozott program keretei között abból a célból, hogy a fiatalok vállalkozóvá válását elősegítsék és népszerűsítsék az önálló vagy társas vállalkozást, ilyen például a GINOP-5.2.3-16 Fiatalok vállalkozóvá válása - Vállalkozás indítási költségeinek támogatása című pályázati program ahol a pozitívan elbírált pályázók minimum kettő maximum 3 millió forintos vissza nem terítendő forrásra tehetnek szert. Az Európai Unió, felismerve a KKV szektorban már működő vállalkozások finanszírozási problémáit létrehozták az úgynevezett COSME (Competitiveness of Enterprises and Small and Medium-sized Enterprises) programot, melynek keretében 2,3 milliárd euróval támogatják a 2014- 2020 közötti tervezési periódusra az érintett vállalkozásokat [2].

$\mathrm{Az}$ önfoglalkoztatásra tekinthetünk úgy, mint az önmegvalósítás egy eszközére azonban közgazdaságtani értelemben ennél többet jelent, fontos szerepet játszik a gazdaság élénkítésében, a foglalkoztatottság növelésében. Azonban Scharle [3] szerint a munkanélküliség veszélye, vagyis az álláslehetőségek beszűkülése általában nem, illetve csak az önfoglalkoztatók bizonyos csoportjaiban a nők és a mezőgazdaságban vállalkozók között - növelheti meg az önfoglalkoztatás valószínűségét.

A vállalkozói készség és az ahhoz szükséges képességek nem természetes úton az egyénnel vele született adottság, inkább egy tanulható folyamat. A jelenlegi helyzet alapján leginkább ezt a fajta gazdasági, jogi, szociális, kulturális tudást a fiatalok csak a felsőoktatási intézményekben szerezhetik meg, ugyanis az alsó- és középfokú oktatásban megszerezhető ismeretanyag eléggé hiányos, nem orientálják a fiatalokat ilyen irányba. Persze ez alól kivétel lehet, ha valaki a családjában lévő saját vállalkozáson keresztül már egészen kis korától fogva szembesül és elsajátítja e tapasztalatokat. A családi vállalkozás meghatározó jellemvonása a tulajdonjog és az irányítás egy kézben való birtoklása, ebből fakadóan a tulajdonjognak és a irányításnak a következő generációra való átadása központi fontosságú, mivel ez az a mechanizmus, amelynek révén a családi vállalkozás reprodukálja önmagát. A generációváltás több részből és indíttatásból is létre jöhet. [4]

Imreh-Tóth és társai szerint „a vállalati, az üzleti és akár a vállalkozásoktatási tevékenység végső célja egyaránt a független vállalkozás létrehozásának és sikeresebb működtetésének ösztönzése" [5]. A vállalati sikertényezőkkel Nagy és Tobak részletesen foglalkozik [6]. Amíg 40-50 évvel ezelőtt a vállalkozások pénzügyi (formális) tervezése volt a vállalati folyamatok sikerességének kulcsa [7], addig mára kimutatható, hogy a gazdaság versenyképességében is egyre jobban felértékelődik a felsőoktatás versenyképességének a szerepe [8]. Azonban annak ellenére, hogy a személy egy felsőoktatási intézményben kompetens szakmai, gazdasági tudást szerez, az üzleti tevékenység 
megkezdésére vonatkozó végső döntés valószínűleg olyan folyamatot tükröz, amelyben a hozzáállás és szándék az egyedi kompetenciák, a tapasztalatok mind összefüggésben vannak az üzleti összefüggésekkel [9]. Krueger és munkatársai [10] ezért azt javasolják, hogy a szándék mögött rejlő attitűdök értékelése nagyobb figyelmet érdemelnek a vállalkozói kutatásban. Tehát tudnunk kell különbséget tenni a tényleges vállalkozói aktivitás és a vállalkozói szándék között, tekintve, hogy ez utóbbi nem feltétlenül realizálódik tényleges vállalkozói tevékenységben [11]. Ugyanakkor jelen kutatás célja maga a szándék meglétének vizsgálata a hallgatók körében.

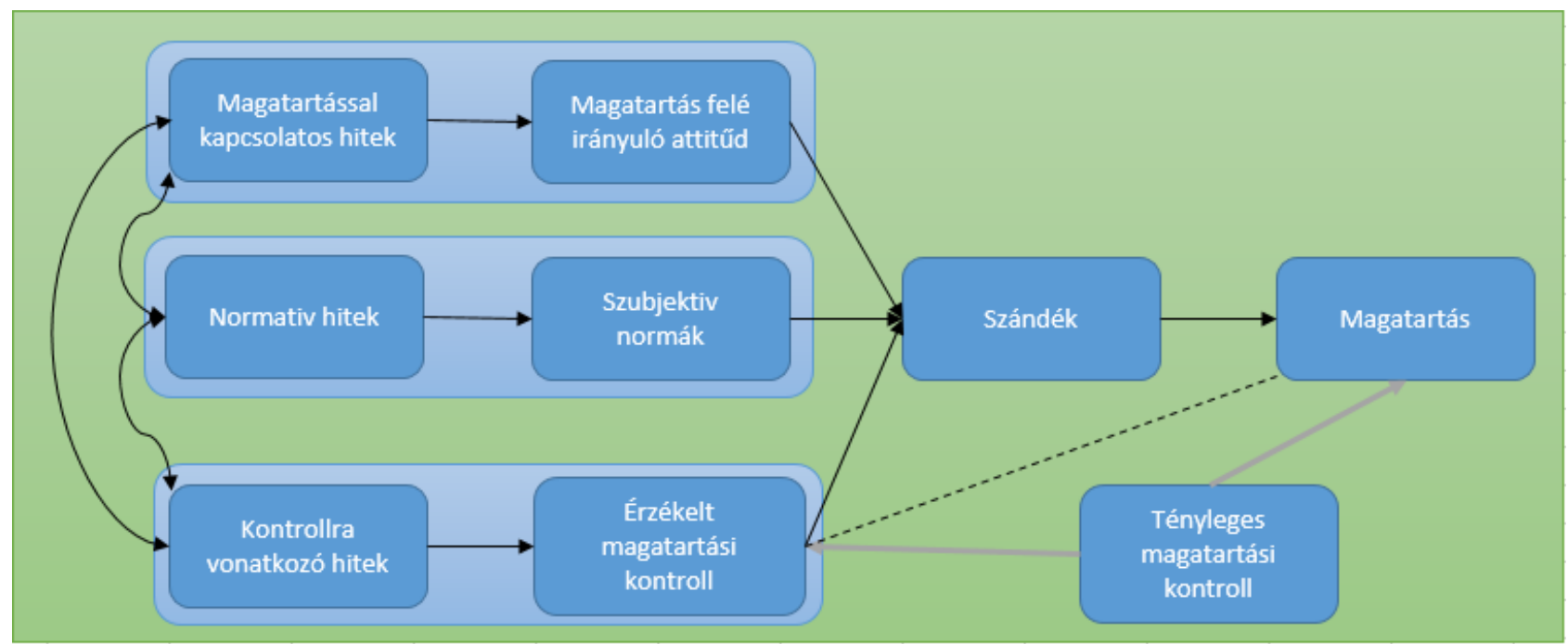

1. ábra: A tervezett cselekvés elmélete

(Forrás: Saját szerkesztés - Ajzen (2016) alapján)

\section{A kutatás módszertana}

A kérdőíves felmérés Debrecenben, a Debreceni Egyetem 14 karának - ÁJK, ÁOK, BTK, EK, FOK, GTK, GYFK, GYTK, IK, MÉK, MK, NK, TTK, ZK - 500 hallgatójával készült 2017. május 22. - 2018. február 28. közötti időszakban. Az adatgyűjtés alapját egy kérdőív képezte, melynek szerkezete az alábbiak szerint került megfogalmazásra.

Demográfiai adatok: A hallgató alapvető adatait tartalmazó mezők, jelen esetben három ilyen kérdés került lekérdezésre, ilyen a hallgató neme, életkora és a településnek a típusa, ahol felnőtt.

Képzéssel kapcsolatos adatok: A hallgató azon adatai kerültek felvezetésre, hogy jelenleg az egyetemi képzési szint mely szakaszát teljesiti, illetve azt a Debreceni Egyetem melyik karán és szakán végzi el a jövőben.

A munkába állás várható idejével kapcsolatos kérdés: tervezi-e a hallgató, hogy közvetlenül a végzettség megszerzése után munkába áll, illetve ha nem, akkor a végzettség megszerzése után mennyi idővel tervez munkába állni?

Jövedelemmel kapcsolatos kérdések: A hallgató saját véleménye vagy tapasztalata alapján eldönthette, hogy szerinte melyik eset a jövedelmezőbb, ha saját vállalkozást indít, vagy ha alkalmazotti jogviszonyban helyezkedik el, vagy pedig a kettő között nincs érdemi különbség. 
Környezeti tényezők: A hallgató saját véleménye alapján eldönti, hogy Magyarországon a jelenlegi gazdasági, és jogi környezet megfelelő környezetet nyújtanak-e saját vállalkozás indítására, illetve melyik megyében vállalkozna legszívesebben, Budapestet külön volt szükséges feltüntetni.

Milyen visszatartó erők vannak a vállalkozással kapcsolatban: A hallgató a feltett potenciálisan visszatartó erőként értelmezett kérdésekre Likert skálán választ adhatott, hogy mennyire akadályozza például a saját tőke hiánya, vagy vállalkozói készségek hiánya.

A kutatás alapsokaságát a Debreceni Egyetem nappali tagozatos képzésben résztvevő hallgatói képezték, négy különböző képzési szintről: felsőoktatási szakképzés, alapképzés, mesterképzés, illetve osztatlan képzés. A mintavételi eljárása során véletlenszerű mintavételt alkalmaztam, a felmérésben részt vevő hallgatók az egyetem 14 karáról, és 37 különböző szakáról került kiválasztásra, kutatásom során az egyetemi kar, mint független változó jelenik meg. Elmondható, hogy a törekvés arra való tekintettel, hogy a Debreceni Egyetem minden tudományterületéről, egyetemi karról kerüljön be hallgató sikeresnek tekinthető. Azonban a reprezentativitás fenntartása érdekében rétegzett mintavételi eljárást használtam, a rétegeket az egyetem karai szolgáltatták ugyanis a kérdőívek kényelmi módszerrel lettek felvéve személyesen az egyetemen vizsgázó csoportok által, illetve online kérődívezéssel, ezért a módszerből eredő hibákat rétegzéssel próbáltam kiküszöbölni. Az eljárás azonban számos előnnyel jár a kutatás során, könnyen elérhető célzott válaszadókat biztosított nagy számban.

A mintavételi eljárásból következik, hogy az alapsokaságból a rétegeket szükséges kialakítani, amelyet jelen esetben az egyetemi karok határozták meg létszámuk arányában. Az Excelben beépített véletlenszám generátorral VÉLETLEN.KÖZÖTT függvénnyel teljesen véletlenül kerültek bele a résztvevő hallgatók. A minta statisztikai értelemben igy reprezentatívnak nevezhető, ugyanis arányaiban teljes mértékben megegyeznek a Debreceni Egyetem nappali tagozatos hallgatóinak összlétszámával a mintára való tekintettel. A mintavétel és maga a minta hitelességét erősiti, hogy nem csak online kérdőívek kerültek kitöltésre, hanem papír alapon is töltöttek ki kérdőíveket a Debreceni Egyetem hallgatói, így bár nagyobb ráfordítás volt a felmérés időbeli vonzata, azonban így talán azok is válaszoltak a kérdésekre, akik egyébként egy online kérdőívet nem töltöttek volna ki.

\begin{tabular}{|c|c|c|c|c|}
\hline Kar & $\begin{array}{c}\text { Összes hallgatói } \\
\text { létszám }\end{array}$ & $\begin{array}{c}\text { Kar létszámának } \\
\text { aránya }\end{array}$ & $\begin{array}{c}\text { Összes } \\
\text { kitöltő }\end{array}$ & $\begin{array}{c}\text { Rétegzett } \\
\text { minta }\end{array}$ \\
\hline ÁJK & 878 & $4 \%$ & 13 & 12 \\
\hline ÁOK & 3730 & $18 \%$ & 61 & 53 \\
\hline BTK & 2456 & $12 \%$ & 44 & 35 \\
\hline EK & 759 & $4 \%$ & 12 & 11 \\
\hline FOK & 691 & $3 \%$ & 16 & 10 \\
\hline GTK & 2905 & $14 \%$ & 56 & 41 \\
\hline GYFK & 458 & $2 \%$ & 8 & 7 \\
\hline GYTK & 527 & $2 \%$ & 12 & 7 \\
\hline IK & 1704 & $8 \%$ & 66 & 24 \\
\hline MÉK & 1435 & $7 \%$ & 44 & 20 \\
\hline
\end{tabular}




\begin{tabular}{|c|c|c|c|c|}
\hline MK & 1891 & $9 \%$ & 32 & 27 \\
\hline NK & 767 & $4 \%$ & 14 & 11 \\
\hline TTK & 2678 & $13 \%$ & 119 & 38 \\
\hline ZK & 210 & $1 \%$ & 3 & 3 \\
\hline Összesen & 21089 & $100 \%$ & 500 & 300 \\
\hline
\end{tabular}

1. táblázat: Hallgatók karonkénti megoszlása

Forrás: (unideb.hu,2017)

\section{Eredmények}

\section{A minta demográfiai jellemzői:}

A kutatásban a mintegy 500 résztvevő hallgató közül a legfiatalabb válaszadó 19 éves, a legidősebb megkérdezett hallgató pedig 29 éves volt, a megkérdezett hallgatók átlag életkora pedig 21 év volt. Képzési szintjük szerint 203 hallgató az alapképzésben vesz jelenleg részt, 5 hallgató felsőoktatási szakképzésben, 23 hallgató mesterképzésben, 69 hallgató pedig osztatlan képzésben folytatja jelenleg tanulmányait. Az alábbi táblázatban a rétegzett minta alapján kapott eredmények láthatóak.

\begin{tabular}{|c|c|c|c|}
\hline Kar & Fő & Átlagéletkor & Családban van vállalkozás \\
\hline ÁJK & 12 & 19,2 & 7 \\
\hline ÁOK & 53 & 20,1 & 30 \\
\hline BTK & 35 & 20,6 & 16 \\
\hline EK & 11 & 21,3 & 4 \\
\hline FOK & 10 & 21,8 & 3 \\
\hline GTK & 41 & 20,8 & 27 \\
\hline GYFK & 7 & 21,1 & 5 \\
\hline GYTK & 7 & 22,0 & 5 \\
\hline IK & 25 & 21,7 & 16 \\
\hline MÉK & 20 & 20,9 & 12 \\
\hline MK & 27 & 23,3 & 13 \\
\hline NK & 11 & 21,5 & 3 \\
\hline TTK & 38 & 20,8 & 22 \\
\hline $\mathrm{ZK}$ & 3 & 23,6 & 2 \\
\hline Összesen: & 300 & 21,3 & 165 \\
\hline
\end{tabular}

\section{2. táblázat: Hallgatók karonkénti megoszlása}

(Forrás: Saját adatgyüjtés, 2017)

A női hallgatók aránya a felmérésben 61\%-os volt, míg a férfi hallgatók 39\%-os aránnyal képviselték magukat a felmérésben. A fenti táblázatból jól látható, hogy az 300 fó a Debreceni Egyetem 14 különböző karáról került megkérdezésre. Jellemzően a Gazdálkodástudományi Kar, a Természettudományi Kar, és az Általános Orvostudományi Kar hallgatóitól jött vissza a legtöbb kitöltött kérdőív. Az átlagéletkor Zenemúvészeti kar esetében volt a legmagasabb 23,6 évvel, illetve az 
Állam- és Jogtudományi Kar hallgatói voltak a legfiatalabbak alig több mint 19 évükkel. Fontosnak tartom megjegyezni, hogy a kérdőívet kitöltő hallgatók kicsivel több, mint a felének, 55\%-uk családjában, valamelyik hozzátartozójuknak van saját vállalkozása. Legalacsonyabb arányban 27\%-kal a Népegészségügyi kar hallgatói, és a Fogorvostudományi kar hallgatói rendelkeztek olyan családtaggal, akinek tulajdonában van vállalkozás, a legmagasabb arányban pedig a Gyógyszerésztudományi kar hallgatói állnak, ahol a hallgatók 71\%-a rendelkezik olyan családtaggal, akinek van valamilyen vállalkozása.

Az alábbi táblázatból látható, hogy a hallgatók milyen számban és milyen arányban élnek életvitelszerűen az adott település kategóriák szerint. Budapestről mindösszesen két fő érkezett, megyeszékhelyekről 75 fő, városból 117-en, 99 faluban vagy községben élő hallgató, és 7 fő külhoni magyar töltötte ki a kérdőíveket.

\begin{tabular}{l|ll} 
TELEPÜLÉS & FŐ & SZÁZALÉK \\
\hline FŐVÁROS & 2 & $0,7 \%$ \\
MEGYESZÉKHELY & 75 & $25 \%$ \\
VÁROS & 117 & $39 \%$ \\
FALU / KÖZSÉG & 99 & $33 \%$ \\
KÜLFÖLD & 7 & $2,3 \%$ \\
ÖSSZESEN & $\mathbf{3 0 0}$ & $\mathbf{1 0 0 , 0 0 \%}$ \\
& 3. táblázat &
\end{tabular}

(Forrás: Saját adatgyújtés, 2017)

Az összes megkérdezett hallgató munkába szeretni állni a diploma kézhezvételét követő három hónapon belül kilenc százalékuk úgy gondolja, hogy az első hónapban, 72 százalék szerint két hónap szükséges hozzá, illetve 19 százalék szerint három hónap szükséges.

A hallgatók azzal a kérdéssel kapcsolatban, hogy elképzelésük szerint mi az amivel magasabb jövedelmet tudnak elérni, vállalkozóként a saját vállalkozásunk bevételeiből előteremtett jövedelem, vagy pedig alkalmazotti jogviszony által megkeresett jövedelem; a válaszadók az alábbiak szerint válaszoltak:

Ön szerint melyik jár magasabb jövedelemmel?

\begin{tabular}{l|lll}
\hline & Férfi & Nö & Összesen \\
Saját vállalkozás & $79,71 \%$ & $80,25 \%$ & $\mathbf{8 0 , 0 0 \%}$ \\
Alkalmazotti jogviszony & $4,35 \%$ & $8,64 \%$ & $\mathbf{6 , 6 7 \%}$ \\
Nincs különbség & $15,94 \%$ & $11,11 \%$ & $\mathbf{1 3 , 3 3 \%}$ \\
Összesen & $100,00 \%$ & $100,00 \%$ & $\mathbf{1 0 0 , 0 0 \%}$ \\
& 4. táblázat & &
\end{tabular}

(Forrás: Saját adatgyűjtés, 2017) 
Elmondható tehát, hogy az összes megkérdezett hallgató tekintetében a 80 százalékuk úgy gondolja, hogy jövedelmezőbb egy saját vállalkozás, mint alkalmazotti jogviszonyban elhelyezkedni egy cégnél. Ellenben 6,7 százalékuk szerint inkább az alkalmazotti jogviszony az, ami a számára nagyobb bevételi forrást jelentene, és közel 13 százalék az, aki szerint semmilyen különbség nincs a két jövedelemszerzési forrás között. Összességében tehát a Debreceni Egyetem hallgatói négyötöde körében az a vélemény, hogy ha vállalkozna, több jövedelmet tudna elérni. Azonban a valóságban ennél jóval kevesebb hallgató fog valószínűleg vállalkozásba kezdeni. Ez valószínúleg annak is köszönhető, hogy a megkérdezettek közel 50 százalékának a családjában található vállalkozás, amelyek tehát feltehetőleg jól működnek, és így ezt találják a jövedelmezőbb megoldásnak.

Kíváncsi voltam arra továbbá, hogy szeretnének-e kifejezetten saját vállalkozást indítani tanulmányaik befejeztével. Látszik, hogy e kérdés tekintetében már jóval megosztottabb a vizsgált minta, de még mindig viszonylag magasnak mondható azoknak az aránya, akik vállalkozóként képzelik el a jövőjüket. Mintegy 37,8 százalékuk adta azt a választ, hogy kifejezetten saját vállalkozást szeretne indítani tanulmánya befejeztével, 23,2 százalékuk adott nemleges választ, ők biztosan nem szeretnének ezzel a lehetőséggel élni, 39 százalék pedig jelenleg nem tudja megmondani vagy eldönteni, hogyan is képzeli el az egyetemi képzés utáni pályáját.

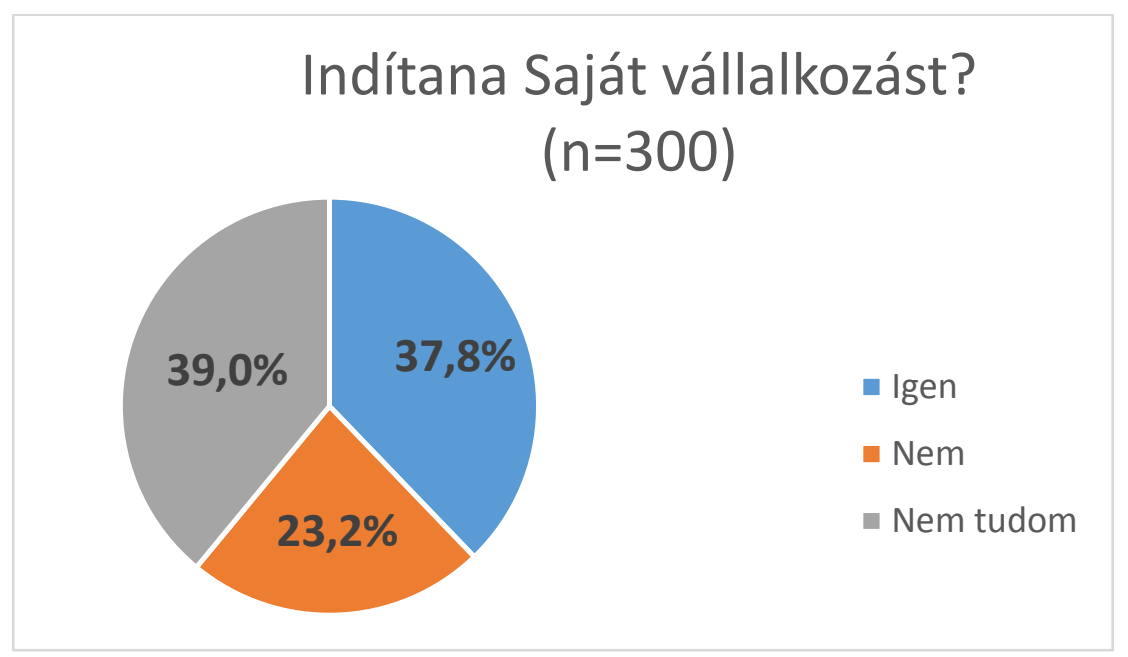

2. ábra

(Forrás: Saját adatgyüjtés, 2017)

Az utóbbi években számos olyan támogató projekt valósult meg Magyarország és az Európai Unió keretein belül, amely a fiatalok vállalkozóvá való válását támogatja vissza- és vissza nem térítendő támogatással. Ilyen például a Széchenyi 2020 keretében megjelent a „Fiatalok vállalkozóvá válásának támogatása" című GINOP pályázat, amely kezdetekor 16 milliárd forint állt rendelkezésre az indulni kívánó fiatal vállalkozók számára, mint saját tőke pótlás. „A program célja a Magyarország kevésbé fejlett régióinak területén új egyéni vagy mikrovállalkozás indítását tervező, vállalkozói szemlélettel rendelkező, 18-30 év közötti fiatalok felkészítése saját vállalkozásuk indítására, üzleti tervük kialakításához nyújtott ismeret- és készségfejlesztéssel, valamint vissza nem térítendő források támogatásával a jóváhagyott üzleti terv alapján indított vállalkozásuk tóketámogatásához. A támogatás mértéke a projekt elszámolható összes költségének 100\%-a lehet." (I2) 


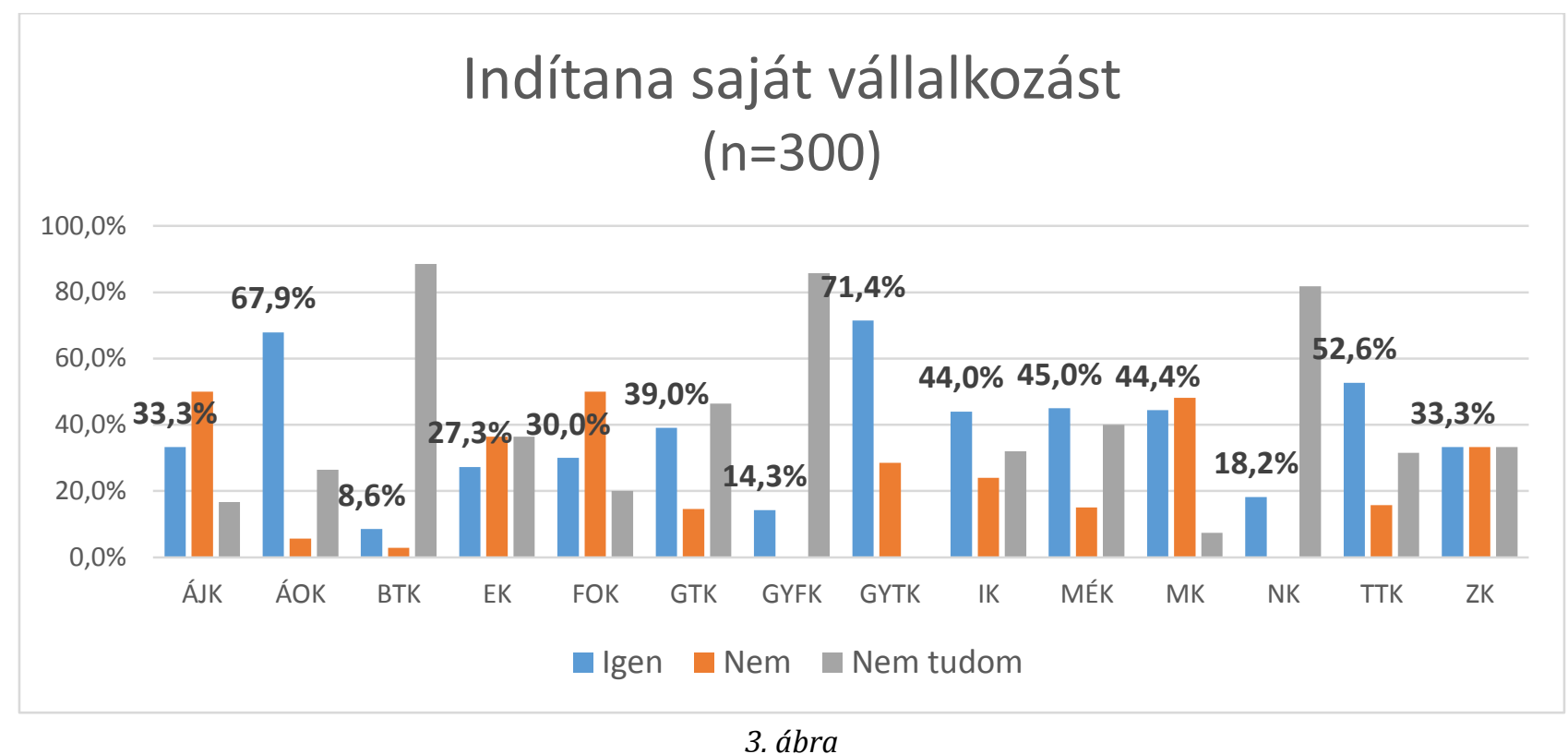

(Forrás: Saját adatgyüjtés, 2017)

Tehát kézenfekvő a kérdés, hogy amennyiben a kitöltő nemmel választolt arra, hogy szeretne-e vállalkozást indítani (3. ábra), vállalkozóvá válást támogató pályázattal hajlandó lenne-e belevágni (4. ábra)? A kiértékelés során arra a következtetésre jutottam, hogy még a teljes mértékben vissza nem terítendő támogatás ellenére sem szeretne a hallgatók közel 40\%-a vállalkozni, egyszerűen nem vonzó ez a pálya számukra. Igenlő választ, tehát, hogy állami támogatással meggondolná magát és hajlandó lenne vállalkozni mindösszesen 13 százalék adott. A nemleges válaszok esetében a nők határozottabban elutasítóak, 43 százalékuk, míg a férfiak 35 százaléka utasítja el a vállalkozást, még abban az esetben is, ha megvalósítandó ötletükre vonatkozó üzleti tervet a pályázat során elfogadnák, és a projekt 100\%-át finanszíroznák. Viszont a válaszadók közel 50 százaléka még nem gondolkozott el azon, hogy ilyen lehetőség mellett melyik válasz mellett kötelezné el magát. 


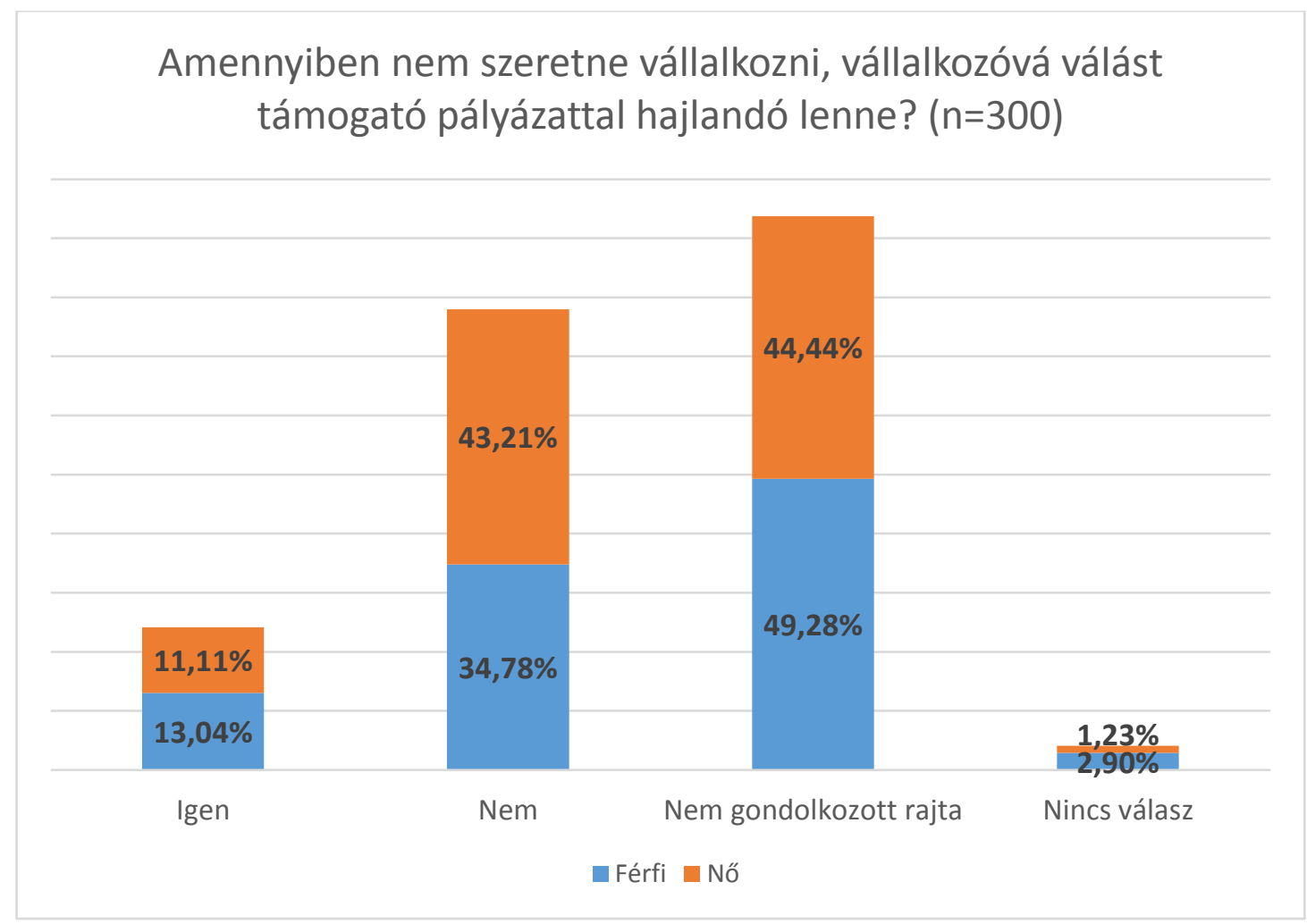

4. ábra

(Forrás: Saját adatgyüjtés, 2017)

Érdemes tehát megvizsgálni, melyek azok a tényezők, amelyek negatív hatássál bírnak a Debreceni Egyetem hallgatóira, és az állami támogatás ellenére sem mernek, vagy akarnak önálló vagy társas gazdasági társaságot létrehozni. A kérdőív keretében négy tényezőről lettek megkérdezve. Ezek voltak a saját tőke hiánya, félelem a sikertelenségtől, kapcsolatrendszer hiánya, vállalkozói készségek hiánya, és mindezt egy öt fokozatú Likert skálán értékelték. Az adatok feldolgozása során az alábbi eredményekre jutottam. A hallgatók szerint a legkevésbé gátló tényező a félelem a sikertelenségtől, csupán 5 százalékuk válaszolta, hogy ez teljes mértékben gátolja ôt abban, hogy vállalkozzon, viszont 23 százalékuk szerint nagyon is meghatározó. Többségben azok a személyek vannak, akik a skála középső és alsó tartományát jelölték meg, 41 százalék mérsékelten, illetve 30 százalék alig, vagy egyáltalán nem fél a sikertelenségtől, ha vállalkozást indítana. A vállalkozói készségek hiánya 18 százalékuk szerint meghatározó, 21 százalékuk szerint nagyon, mérsékelt véleményen 37 százalék volt, és 24 százalékuk szerint ez nem jelent problémát, ezek tanulható képességek. Hasonlóan gondolkoznak a kapcsolatrendszer hiányáról is; 14 százalék szerint teljes mértékben gátolja őt vállalkozás indításában, hogy nem rendelkezik a megfelelő kapcsolatokkal az üzleti életben, 34 százalék szerint ez nagyon fontos lenne, de nem rendelkezik kapcsolatokkal, mérsékelten gátló 36 százalék szerint, 16 százalék viszont úgy gondolja, hogy ez nem akadály, ezekre a kapcsolatokra a vállalkozás beindítása során is szert tudnak tenni. 


\section{Visszatartó tényezők a vállalkozás indításától $(n=300)$}

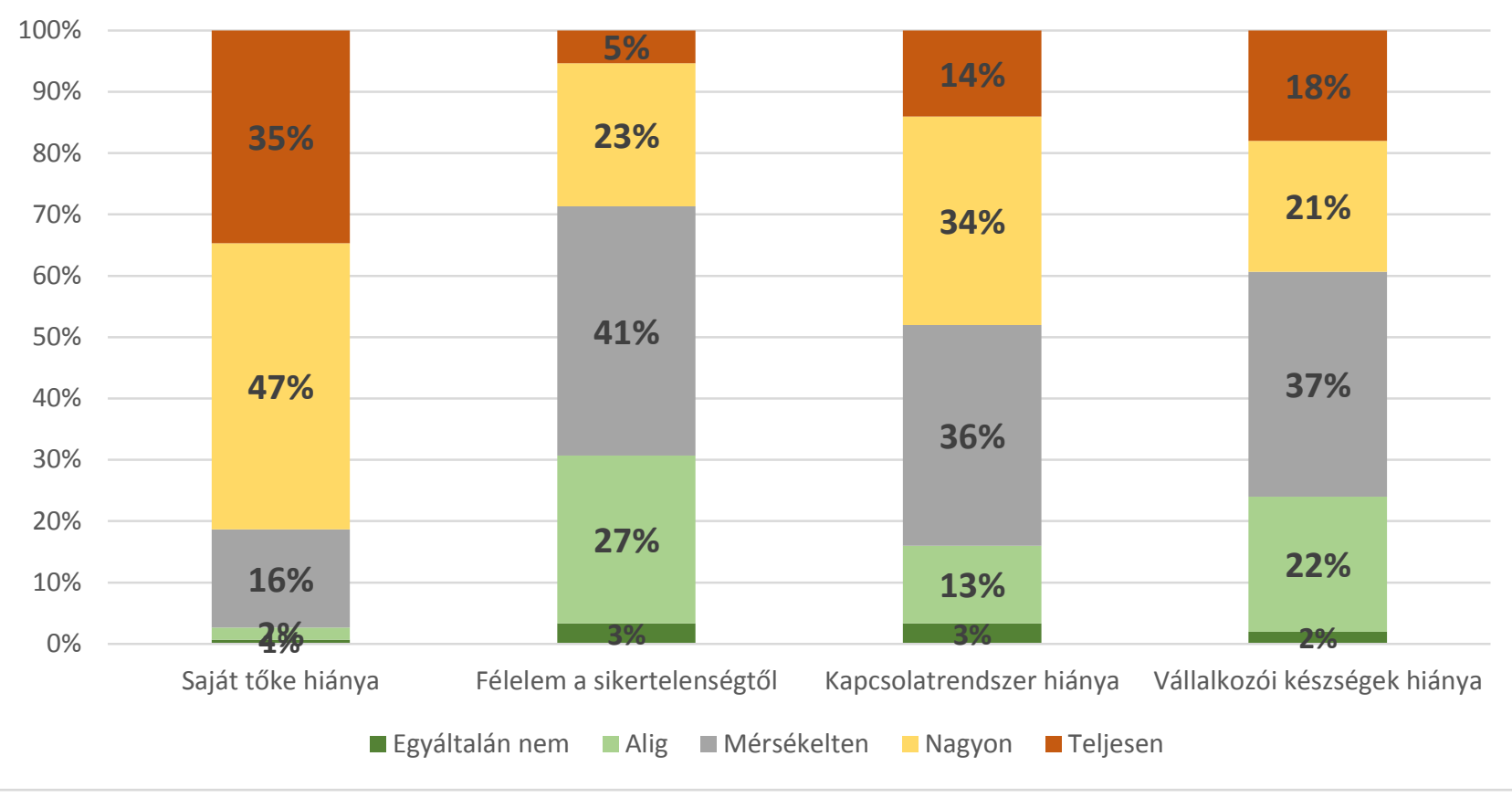

5. ábra

(Forrás: Saját adatgyüjtés, 2017)

Viszont a leginkább gátló tényező az a saját tőke hiánya volt, a megkérdezett hallgatók 82 százaléka gondolja úgy, hogy a tőkehiány teljesen mértékben vagy nagyon meghatározó mértékben tartja vissza attól, hogy vállalkozást indítson, akik közepes mértékben értékelik a tőkehiányt gátló tényezőnek, ők is a teljes minta 16 százalékát teszik ki, és mindösszesen 3 százalékuk az, aki úgy gondolja, hogy a tőkehiány nem akadály. Voltak azonban olyan válaszadók, a kitöltők közel 17 százaléka, akik szeretnének saját vállalkozást indítani, annak ellenére, hogy számukra a legnagyobb visszatartó erőt a saját tőke hiánya okozza. Azonban nem gondolkoztak el, vagy nem hallottak arról, hogy pályázat útján az induló vállalkozása bekerülési értékét állami támogatásból teljes mértékben finanszírozhatná. Pontosan azért jöttek létre ezek a programok, hogy ezt az egyébként egy vállalkozás beindításánál igen meghatározó akadályt elhárítsa. Tehát célszerű lenne ezeket a programokat és információkat a fiatalok felé hatékonyabban közölni. Továbbá jöttek olyan visszajelzések, hogy a szakmai felkészültség hiánya, hiányos tudás, ötlettelenség, motiváció és kitartás hiánya mind-mind akadályozzák őket a vállalkozóvá válásban.

Felmerül a kérdés, hogy ha új vállalkozásba kezdene, mi alapján döntené el a hallgató a potenciális vállalkozás profilját? A vizsgált minta alapján $48 \%$ százalék új termék vagy szolgáltatás bevezetésével próbálkozna, tehát a piaci rések betömésére irányuló akciókat terveznek. A válaszadók 40\%-a nem ennyire innovatív, és inkább a már a piacon megtalálható termékek vagy szolgáltatásokat fejlesztené tovább, és dobná piacra, volt viszont 9\%, aki nem próbálna semmilyen piaci rést vagy innovatív fejlesztést találni, ugyanazt a terméket próbálná értékesíteni, mint a versenytársai. 


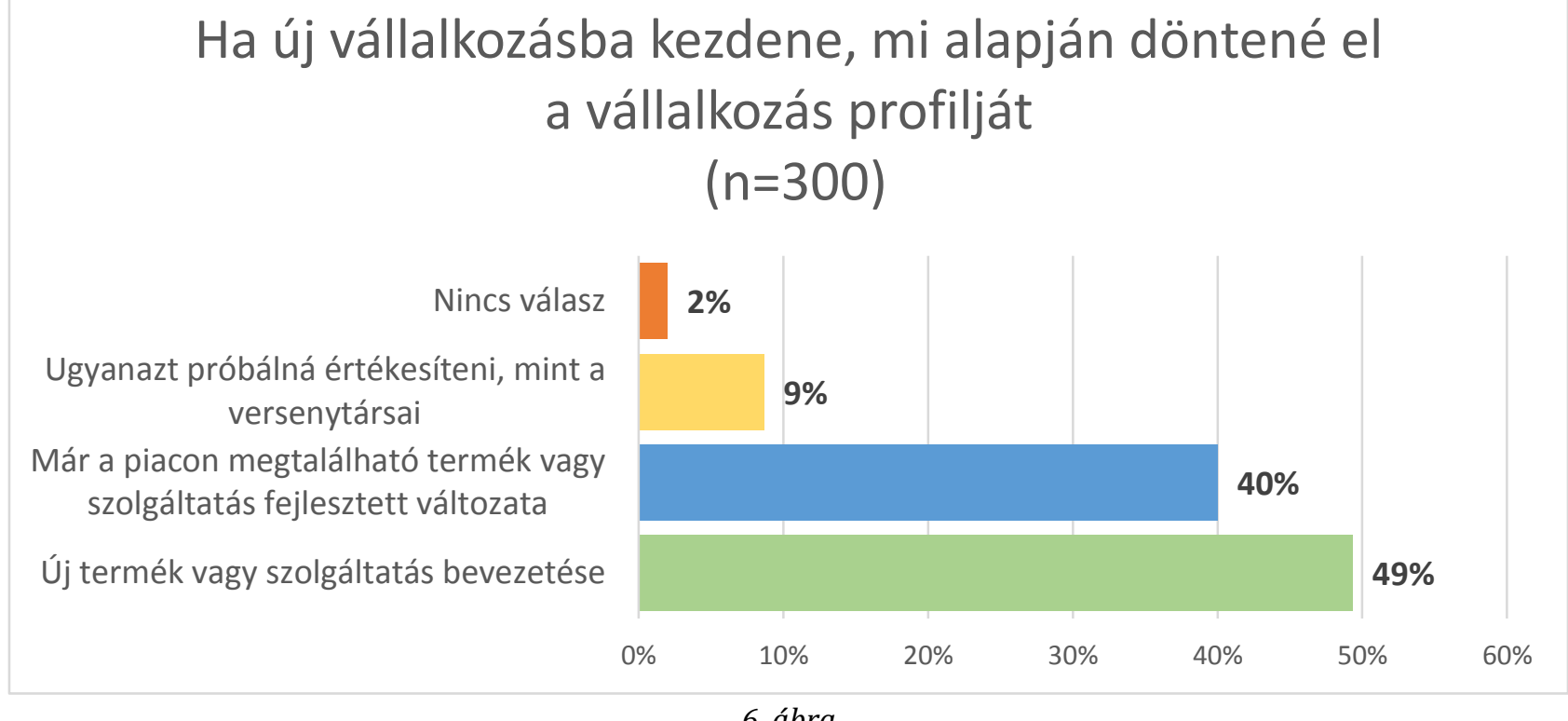

(Forrás: Saját adatgyüjtés, 2017)

Az 5. táblázatból látható jellemzően milyen válaszok érkeztek vissza arra vonatkozóan, milyen vállalkozást alapitanának a hallgatók. Általánosságban elmondható, hogy a hallgatók egy része saját szakterületén szeretne vállalkozni, azonban számos olyan válasz érkezett, amely hallgatóknál tanulmányaik és vállalkozói szándékuk területe között nincs kapcsolat, például volt olyan bölcsész hallgató aki innovatív asztalos vállalkozást indítana, de a TTK-ról is volt aki az árnyékolástechnikában lát lehetőséget. Mindez azt jelenti, hogy a vállalkozni kívánó hallgatók próbálják a piaci réseket megtalálni.

\section{Milyen típusú vállalkozást szeretne}

\begin{tabular}{|c|c|c|c|c|c|}
\hline \multirow{7}{*}{ 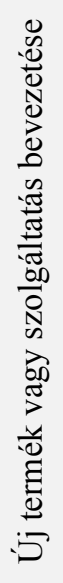 } & Asztalos & \multirow{7}{*}{ 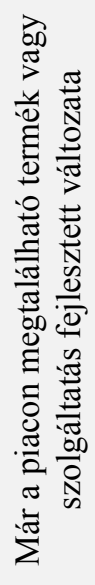 } & Árnyékolástechnika & \multirow{7}{*}{ 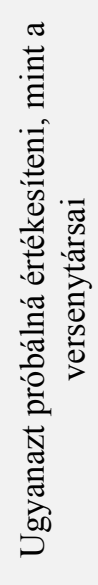 } & Állattenyésztés \\
\hline & Élelmiszerbolt & & Borászat & & Vendéglátás \\
\hline & Építőipari vállalkozás & & Egészségügy & & Mezőgazdaság \\
\hline & Faipari vállalkozás & & $\begin{array}{l}\text { Élelmiszeripari } \\
\text { vállalkozás }\end{array}$ & & Autóbérbeadás \\
\hline & Informatika & & Fémmegmunkálás & & $\begin{array}{l}\text { Autókereskedés és } \\
\text { szerviz }\end{array}$ \\
\hline & Kereskedelemi vállalkozás & & Festő, Mázoló & & Egészségügy \\
\hline & Mezőgazdasági vállalkozás & & Fogorvosi praxis & & $\begin{array}{l}\text { Jótékonysági } \\
\text { Alapítvány }\end{array}$ \\
\hline
\end{tabular}

5. táblázat

(Forrás: Saját adatgyüjtés, 2017) 
Melyik megyében vállalkozna?

Az 500 megkérdezett hallgató közül csak 69 hallgató adott arra választ, hogy Magyarország melyik megyéjében szeretne vállalkozni, ha a tanulmányai után saját vállalkozást indítana. Egyetlen hallgató volt, aki nem magyarországi vállalkozást indítana, hanem az Egyesült Királyság területén, az ottani építőiparban szeretne szerencsét próbálni.

Az alábbi ábrán (7. ábra) látszik, hogy a Debreceni Egyetem megkérdezett hallgatói az ország melyik részében szeretnének céget alapítani. A legtöbben Hajdú-Bihar megyén belül, és Budapesten képzelik ezt el, 38\%, illetve 25\% szeretne ezen a földrajzi területen vállalkozást alapitani. Népszerű még továbbá Győr-Moson-Sopron megye, és Szabolcs-Szatmár-Bereg megye 11\% és 9\%-kal, az ország többi részét kifejezetten a Dél-alföldi régiót nem preferálták.

\section{Melyik megyében vállalkozna?}

$$
(n=300)
$$

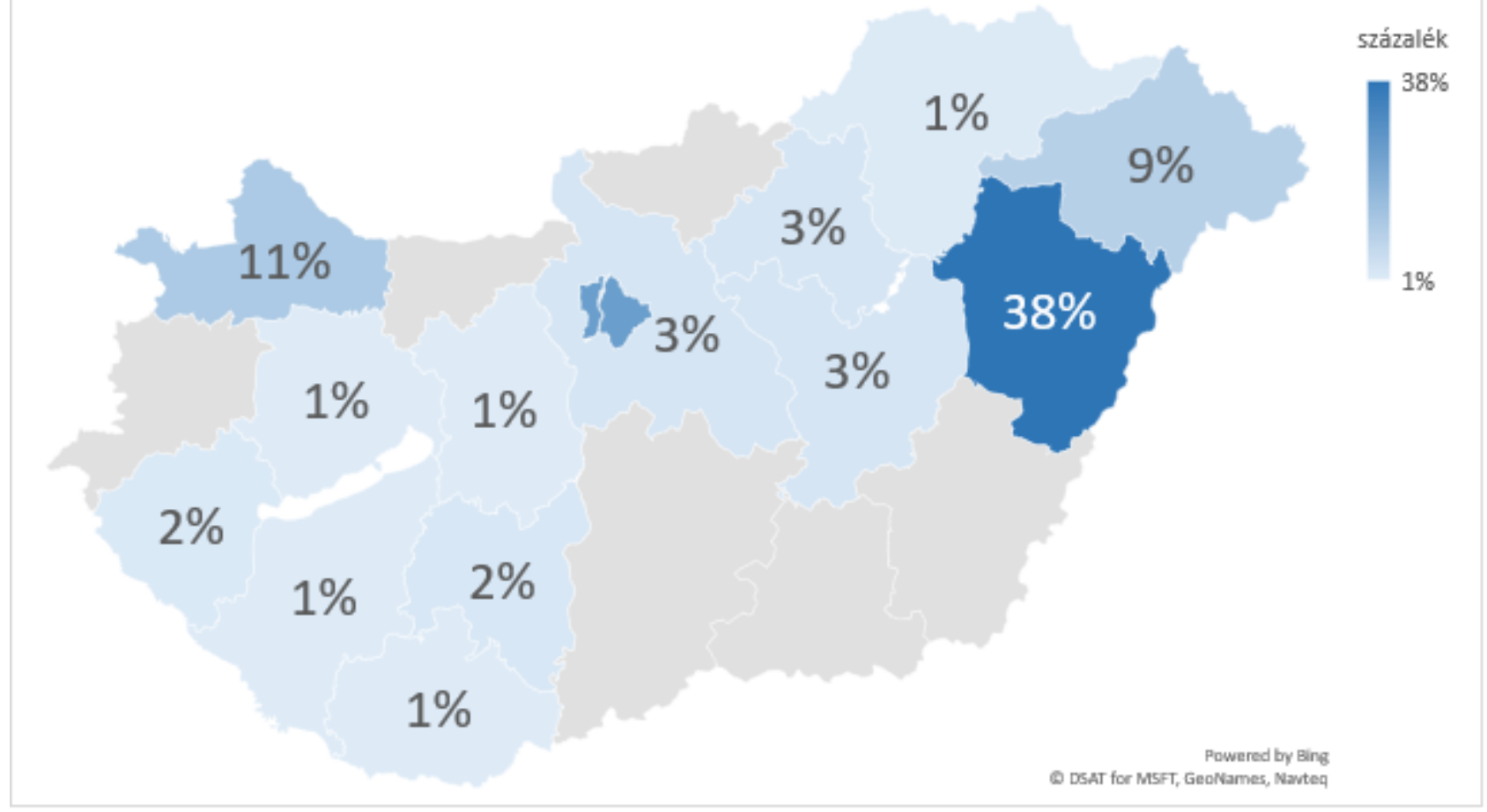

\section{7. ábra}

(Forrás: Saját adatgyüjtés, 2017)

Az alább látható táblázat jól szemléleti (6. táblázat), hogy mely kar hallgatói azok, akik között arányaiban a legtöbben vállalkoznának. A vizsgált mintában a Gyógyszerésztudomány kar hallgatói és az Általános Orvostudományi kar hallgatói a leginkább érdekeltek abban, hogy saját vállalkozást indítsanak, tehát a gyógyszerészek a saját gyógyszertár üzemeltetését, az általános orvosok pedig a magán rendelést részesítik előnyben. A GTK hallgatói mindösszesen a hatodik helyen vannak jelen a felmérésben. A hallgatók az összes karról átlagosan 36 százalékban kívánnak csak saját vállalkozást indítani. Legkevésbé érdekeltek saját vállalkozásban a Bölcsésztudományi kar hallgatói, mindössze kilenc százalékuk szeretne vállalkozást indítani. Megfigyelhető, hogy a magasabb arányban vállalkozni 
akaró karok saját szakterületükön maradnának, addig azokon a karokon ahol alacsonyabb a vállalkozási hajlandóság ott sokkal diverzifikáltabbak a működési területek.

\begin{tabular}{|l|l|l|l|}
\hline Ssz. & Kar & Vállalkozna & Jellemzó válasz \\
\hline 1. & GYTK & $71 \%$ & Gyógyszertár, egészségügy \\
\hline 2. & ÁOK & $68 \%$ & Magán praxis \\
\hline 3. & TTK & $53 \%$ & Kereskedelem, vegyipar \\
\hline 4. & MK & $48 \%$ & Építőipar, mezőgazdaság \\
\hline 5. & EK & $45 \%$ & Kereskedelem, egészségügyi szolgáltatások \\
\hline 6. & MÉK & $45 \%$ & Mezőgazdaság \\
\hline 7. & IK & $44 \%$ & Kereskedelem, informatikai szolgáltatások \\
\hline 8. & GTK & $39 \%$ & Kereskedelem, vendéglátás, mezőgazdaság \\
\hline 9. & ÁJK & $33 \%$ & Ügyvédi iroda \\
\hline 10. & ZK & $33 \%$ & Vendéglátás \\
\hline 11. & FOK & $30 \%$ & Magán praxis \\
\hline 12. & NK & $18 \%$ & Kereskedelem, vendéglátás \\
\hline 13. & GYFK & $14 \%$ & Vendéglátás, családi napközis szolgáltatás \\
\hline 14. & BTK & $6 \%$ & Kereskedelem, nyomdaipar \\
\hline
\end{tabular}

6. táblázat

(forrás: saját adatgyújtés, 2017)

\section{Következtetések}

Mivel a magyar gazdaság meghatározó szereplője a vállalkozói szektor és a benne szereplő vállalkozók, így érdemesnek tartottam megvizsgálni a Debreceni Egyetem hallgatóinak saját vállalkozás indítására irányuló hajlandóságát. A vizsgált minta alapján, ami az egyetem tíz különböző karának, 500 hallgatójával készült elmondható, hogy az összes megkérdezett hallgató munkába szeretni állni a diploma kézhezvételét követő 3 hónapon belül. Mintegy 46 százalék adta azt a választ, hogy kifejezetten saját vállalkozást szeretne indítani tanulmányai befejeztével, 16 százalékuk adott nemleges választ, ők alkalmazottként képzelik el a jövőjüket, 38 százalékuk pedig jelenleg nem tudja megmondani vagy eldönteni, hogyan is képzelik el az egyetemi képzés utáni pályát. Fontosnak tartom megjegyezni, hogy azon hallgatók akik szeretnének vállalkozni nem biztos, hogy később ténylegesen vállalkozást fognak alapitani, a tanulmány célja magának a szándéknak a meglétének felkutatására irányult. Ahhoz, hogy valóban mérni lehessen milyen arányban kerülnek ki vállalkozók utánkövetést kell alkalmazni. A kiértékelés során arra enged következtetni, hogy a hallgatók nem ismerik azokat a pályázati lehetőségeket, amelyekkel vállalkozásuk kezdeti befektetését állami támogatásból, vagy kedvezményes feltételekkel felvehető kölcsönökből finanszírozni tudnák. Így célszerű lenne e lehetőségek hatékonyabb promótálása. A leginkább érdekeltek vállalkozás indításában a Gyógyszerésztudományi kar és az Általános Orvostudományi kar hallgatói, akik végzettségüknek megfelelően saját gyógyszertárt, illetve magán rendelőt kívánnak üzemeltetni, így célzottan az egészségügyi szektor számára is érdemes lenne vállalkozói támogatást biztosítani. Viszonylag magas ugyancsak a TTK, MÉK és IK hallgatók aránya, akik szintén a saját tanulmányi területükhöz kapcsolódó 
vállalkozást kívánnak indítani. Legkevésbé a GTK, MK, FOK, NK és BTK hallgatói szeretnének kockáztatni, és saját vállalkozásba kezdeni. Mindezek alapján fontosnak tartom az újabb pályázat útján elnyerhető forrásokat a fiatal vállalkozó jelöltek számára, azonban intenzívebb marketing kampány szükséges ahhoz, hogy ez az információ mindenkihez eljusson. Ebből arra következtetek, hogy nagyobb média visszhang mellett többen vállalkoznának, ugyanis a hajlandóság megvan, de nincs ami motiválja a hallgatókat.

\section{Hivatkozások}

[1] KSH (2016): A kis- és középvállalkozások helyzete hazánkban, 2016

[2] L. Borbás (2013) Access to finance as main chellange for European SMEs. Can COSME help between 2014-2020? In: 11th International Conference on Management, Enterprise and Benchmarking. 1-2 June 2013. Budapest. pp. 227-233.

[3] Á. Scharle (2000) Önfoglalkoztatás, munkanélküliség és családi kisvállalkozások Magyarországon. Közgazdasági Szemle, 47 pp. 250-274.

[4] M. Imreh-Tóth - Sz. Imreh - Sz. Prónay - M. Vilmányi - M. Lukovics- P. Kovács (2011) Vállalkozásoktatás a felsőoktatásban: lehetôségek és remények. SZTE Gazdaságtudományi Kar Közleményei. JATEPress, Szeged. (megjelenés alatt)

[5] Sz. Nagy - J. Tobak (2017) Családi vállalkozások vezetési és utódlási kérdései. Taylor: Gazdálkodás- és Szervezéstudományi Folyóirat: A virtuális intézet Közép Európa kutatására közleményei, 9 (2) pp. 188-196.

[6] Nábrádi - A. Nagy (2007) A vállalkozások müködtetése az Európai Unióban, Szaktudás Kiadó Ház, Budapest. ISBN 978-963-9736-36-8. pp. 95

[7] A. Nagy - J. Tobak (2016) Vállalati sikertényezôk. GRADUS, 3 (1) p. 433.

[8] K. Barakonyi (2010) A felsőoktatás versenyképességéről. Vezetéstudomány, (41) 12 pp. 4-19.

[9] P. Davidsson (1991) Continued Entrepreneurship: Ability, Need, and Opportunity as Determinants of Small Firm Growth. Journal of Business Venturing, 6 (6) pp. 405-429.

[10] N. F. Jr. Krueger - M. D. Reilly - A. L. Carsrud (2000) Competing models of entrepreneurial intentions. Journal of Business Venturing, 15 (5-6) pp. 411-432.

[11] Z. Bartha - S. A. Gubik (2016) Mennyire befolyásolják a fiatalok vállalkozó kedvét a kulturális gyökerek? In.: Cs. Csiszár (szerk.): Jubileumi tanulmánykötet Illés Mária professzor asszony 70. születésnapjára. Miskolci Egyetem, Miskolc. pp. 15-26.

[12] I. Ajzen (2006) Constructing a Theory of Planned Behavior Questionnaire - Brief Description of the Theory of Planned Behavior.

I1:https://unideb.hu/hu/node/896

I2:https://www.palyazat.gov.hu/megjelent-a-fiatalok-vllalkozv-vlsnak-tmogatsa-cm-felhvs-1 